\title{
Desain Monitoring Human Tracking dengan RFID dan GPS
}

\author{
Haris Isyanto ${ }^{1}$, Wahyu Ibrahim ${ }^{2}$, Zata Aqmarina Meilisha ${ }^{3}$ \\ ${ }^{1,2,3)}$ Teknik Elektro Universitas Muhammadiyah Jakarta \\ Jl. Cempaka Putih Tengah 27 No 47 \\ Email: ${ }^{1)}$ haris.isyanto@ ftumj.ac.id, ${ }^{3)} 2013420071 @$ ftumj.ac.id
}

\begin{abstract}
ABSTRAK
Di zaman yang modern seperti sekarang ini, absesnsi karyawan sangatlah penting dan menjadi sebuah acuan suatu perusahaan untuk menilai peforma dan kedisiplinan serta kejujuran karyawan dalam bekerja, sama halnya karyawan yang lingkup kerjanya tidak hanya didalam ruangan melainkan di luar ruangan / di lapangan. Tetapi bersamaan dengan hal itu, beberapa karyawan yang bekerja / tugas di luar ruangan seringkali tidak disiplin, pada saat jam kerja karyawan tersebut tidak dalam lingkup kerjanya, melainkan pergi ke suatu tempat yang tidak dikehendaki oleh perusahaan ataupun atasannya. Atas latar belakang itulah maka dirancang sebuah alat human tracking untuk memantau keberadaan karyawan tersebut yang sedang bertugas di lapangan atau tidak dalam area kerjanya. Alat yang dibuat menggunakan microcontroller Arduino pro mini, RFID, SIM808 yang dirancang se-portable mungkin sehingga mudah dibawa kemanapun. RFID berfungsi sebagai identitas karyawan yang sudah terdaftarkan, ketika tag RFID terbaca oleh RFID reader maka GPS dan SIM808 akan aktif yang dikontrol oleh Arduino kemudian data maps yang ter-record akan mengirimkan ke server yang dapat dilihat pada aplikasi Blynk IoT. Dengan begitu memonitoring keberadaan karyawan tersebut cukup dengan smartphone agar selalu dalam pengawasan tanpa karyawan tersebut melaporkan posisi keberadaannya.
\end{abstract}

Kata Kunci : Arduino Pro mini, SIM808, RFID, Blynk IoT, Android

\begin{abstract}
In modern times like today, employee abscess is very important and becomes a reference for a company to assess employee performance and discipline as well as honesty in working, just as employees whose scope of work is not only indoors but outdoors / in the field. But along with that, some employees who work / work outside the room are often undisciplined, when the employee's working hours are not within the scope of work, but go to a place that is not desired by the company or his supervisor. It was against this background that a human tracking tool was designed to monitor the presence of these employees who were on duty in the field or not in their work area. The device is made using an Arduino pro mini microcontroller, RFID, SIM808 which is designed as portable as possible so it is easy to carry anywhere. RFID functions as a registered employee's identity, when the RFID tag is read by the RFID reader, the GPS and SIM808 will be activated which is controlled by Arduino then the recorded map data will send to the server which can be seen on the Blynk IoT application. That way monitoring the employee's whereabouts is enough with a smartphone so that it is always under surveillance without the employee reporting their position.
\end{abstract}

\section{Keywords: Arduino Pro mini, SIM808, RFID, Blynk IoT, Android}

\section{PENDAHULUAN}

Kebutuhan akan sistem monitoring human tracking dalam jarak jauh semakin meningkat dimana perpindahan dan pergerakan manusia semakin luas dan cepat. Di kota besar aktifitas setiap individu masyarakat sangatlah padat, dimana masyarakat sibuk akan pekerjaannya yang memakan waktu. Dalam lingkungan pekerjaan pun karyawan dituntut berlaku jujur dan absensi karyawan sangatlah penting serta menjadi sebuah acuan suatu perusahaan untuk menilai peforma dan kedisiplinan serta kejujuran karyawan dalam bekerja, sama halnya karyawan yang lingkup kerjanya tidak hanya didalam ruangan melainkan di luar ruangan / di lapangan. Tetapi bersamaan dengan hal itu, beberapa karyawan yang bekerja / tugas di luar ruangan seringkali tidak disiplin, pada saat jam kerja karyawan tersebut tidak dalam lingkup kerjanya, melainkan pergi ke suatu tempat yang tidak dikehendaki oleh perusahaan ataupun atasannya. Akibatnya banyak karyawan saat jam kerja tidak dalam area kerjanya dan pekerjaan menjadi terbengkalai.

Pesatnya perkembangan teknologi di zaman ini, dapat diselaraskan dengan gaya hidup manusia yang semakin dinamis [1]. Pada era modern ini teknologi berkembang dengan pesat, tapi berbeda dengan teknologi pengaman sepeda motor 
saat ini [2]. Pada masa sekarang ini teknologi automatisasi berbasis internet IoT (Internet of Things) adalah salah satu teknologi yang popular dan terus berkembang [3]. Arduino adalah perangkat keras dan perangkat lunak sumber terbuka, sehingga pembaca dapat mengunduh perangkat lunak dan gambar dari sirkuit Arduino tanpa harus membayar kepada pembuat Arduino [4]. Semakin pesatnya perkembangan dunia otomotive khususnya kendaraan roda 4 atau yang sering kita sebut mobil, mendorong para produsen kendaraan mobil ini untuk berinovasi mengembangkan teknologi pada kendaraan yang di produksi [5]. Dalam perkembangan teknologi saat ini, listrik menjadi salah satu kebutuhan yang sangat penting bagi kehidupan masyarakat, baik dalam rumah tangga maupun dalam bidang industri [6]. Energi sangat penting untuk manusia untuk bisa bertahan hidup [7]. Pada saat ini berkembang pesat pembangunan gedung gedung pencakar langit di berbagai belahan dunia dan gedung tersebut pasti membutuhkan transportasi vertical [8]. Material organik telah menjadi perhatian para peneliti meskipun karakternya kurang dari silicon [9]. Saat ini, perkembangan dunia teknologi yang demikian mengagumkan itu telah membawa manfaat yang luar biasa bagi kemajuan peradaban umat manusia [10]. Pada perkembangan teknologi saat ini perusahaan perusahaan semakin gencar untuk mendatangkan mesin - mesin dengan teknologi - teknologi cangih dan modern, sehingga perusahaan pun semakin ketat untuk dapat menghasilkan produk - produk dengan kualitas dan mutu yang baik dan tepat sasaran serta efektif dan efesien [11]. Energi matahari dimanfaatkan sebagai sumber energi alternatif yang potensial [12]. Termoelektrik adalah fenomena di mana energi panas diubah menjadi listrik dan sebaliknya [13]. Salah satu bahan semikonduktor organik yang sering digunakan adalah pentacene karena ketersediaannya dan kinerja divaisnya [14]. Sumber energi fosil seperti minyak bumi, gas alam dan batubara akan bisa bertahan jika sumber energi terbarukan digunakan [15].

Arduino, pengendali mikro single-board yang bersifat open-source, diturunkan dari Wiring platform, dirancang untuk memudahkan penggunaan elektronik dalam berbagai bidang. Hardwarenya memiliki prosesor Atmel AVR dan softwarenya memiliki bahasa pemrograman sendiri. Saat ini Arduino sangat populer di seluruh dunia [16].

RFID merupakan sebuah metode identifikasi dengan menggunakan sarana yang disebut label RFID atau transponder untuk menyimpan dan mengambil data jarak jauh. Label atau kartu RFID adalah sebuah benda yang bisa dipasang atau dimasukkan didalam sebuah produk, hewan atau bahkan manusia dengan tujuan untuk identifikasi menggunakan gelombang radio. Label RFID berisi informasi yang disimpan secara elektronik dan dapat dibaca hingga beberapa meter jauhnya. Sistem pembaca RFID tidak memerlukan kontak langsung seperti sistem pembaca kode batang (barcode) [17].

GPS merupakan sistem untuk menentukan letak di permukaan bumi dengan bantuan penyelarasan (synchronization) sinyal satelit. Sistem ini menggunakan 24 satelit yang mengirimkan sinyal gelombang mikro ke Bumi. Sinyal ini diterima oleh alat penerima di permukaan, dan digunakan untuk menentukan letak, kecepatan, arah, dan waktu. Sistem yang serupa dengan GPS antara lain GLONASS Rusia, Galileo Uni Eropa, IRNSS India. GPS Tracker atau sering disebut dengan GPS Tracking adalah teknologi AVL (Automated Vehicle Locater) yang memungkinkan pengguna untuk melacak posisi kendaraan, armada ataupun mobil dalam keadaan Real-Time. GPS Tracking memanfaatkan kombinasi teknologi GSM dan GPS untuk menentukan koordinat sebuah objek, lalu menerjemahkannya dalam bentuk peta digital [18].

Maka dari itu, dilakukan penelitian perancangan sebuah prototype aplikasi sistem human tracking yang dibangun berbasis arduino \& menggunakan rfid sebagai absensi karyawan dan memanfaatkan GPS untuk mengetahui keberadaan orang tersebut, sebagai solusi alternatif baru untuk memonitor human tracking dalam jarak jauh. Sistem pengendalian yang dibangun memanfaatkan jaringan GSM dan internet untuk pengiriman lokasi atau maps yang telah diatur untuk bisa dipantau. Hal ini yang menjadi latar belakang untuk melakukan penelitian yang berjudul "IMPLEMENTASI HUMAN TRACKING MENGGUNAKAN GPS DAN RFID BERBASIS ARDUINO”.

\section{METODOLOGI}

BLOK DIAGRAM SYSTEM HUMAN TRACKING MENGGUNAKAN RFID DAN GPS.

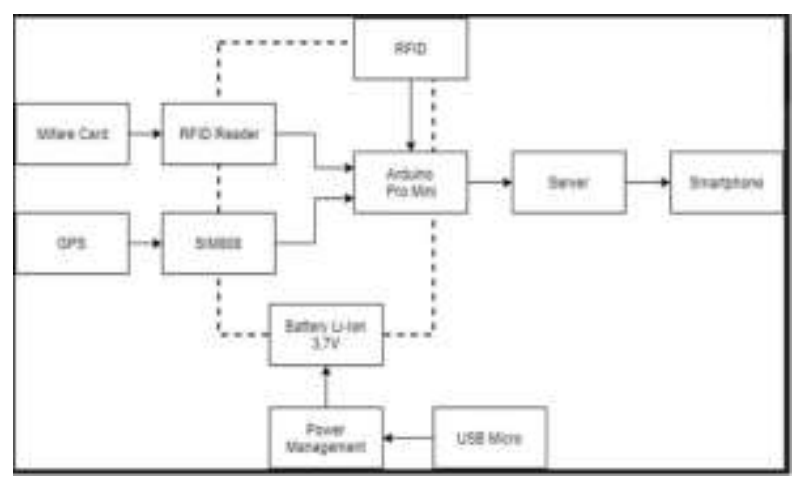


RESISTOR (Elektronika Kendali Telekomunikasi Tenaga Listrik Komputer) Vol. 3 No. 1 e-ISSN : 2621-9700, p-ISSN : 2654-2684

Gambar 1 Blok diagram system human tracking menggunakan RFID dan GPS.

Maksud dari blok diagram system Human Tracking menggunakan RFID dan GPS yaitu membuat sebuah sistem human tracking pada karyawan yang posisi karyawan tersebut jauh dari jangkauan untuk memonitornya dengan memanfaatkan sensor RFID yang menggunakan komunikasi via gelombang elektromagnetik. Dalam sistem ini, tag identifikasi tiap ID Card harus sudah terdaftar, apabila ID Card tidak terdaftar maka RFID Reader akan memberikan notifikasi "Unknown". RFID yang terdaftar bisa lebih dari 5 ID, dalam perancangan sistem kali ini akan dilakukan 2 pendaftaran ID dalam sistem. SIM808 yang merupakan modul GSM dan GPS dalam satu modul yang akan berfungsi mengirimkan titik koordinat yang kemudian informasi dapat diperoleh melalui sebuah aplikasi android yaitu Blynk IoT.

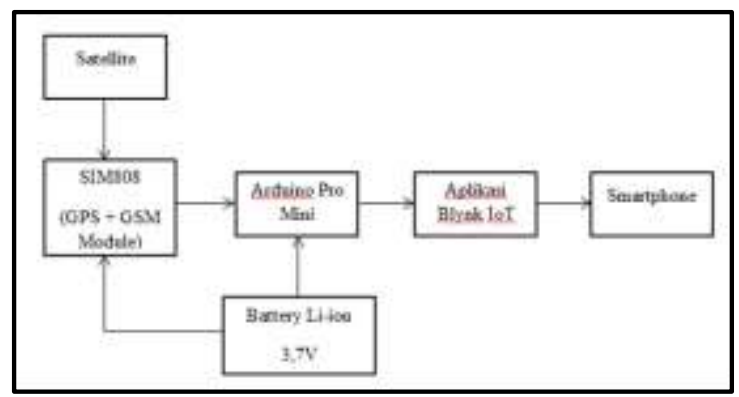

Gambar 2 Blok diagram system GPS.

Flowchart sistem implementasi human tracking menggunakan GPS dan RFID berbasis arduino.

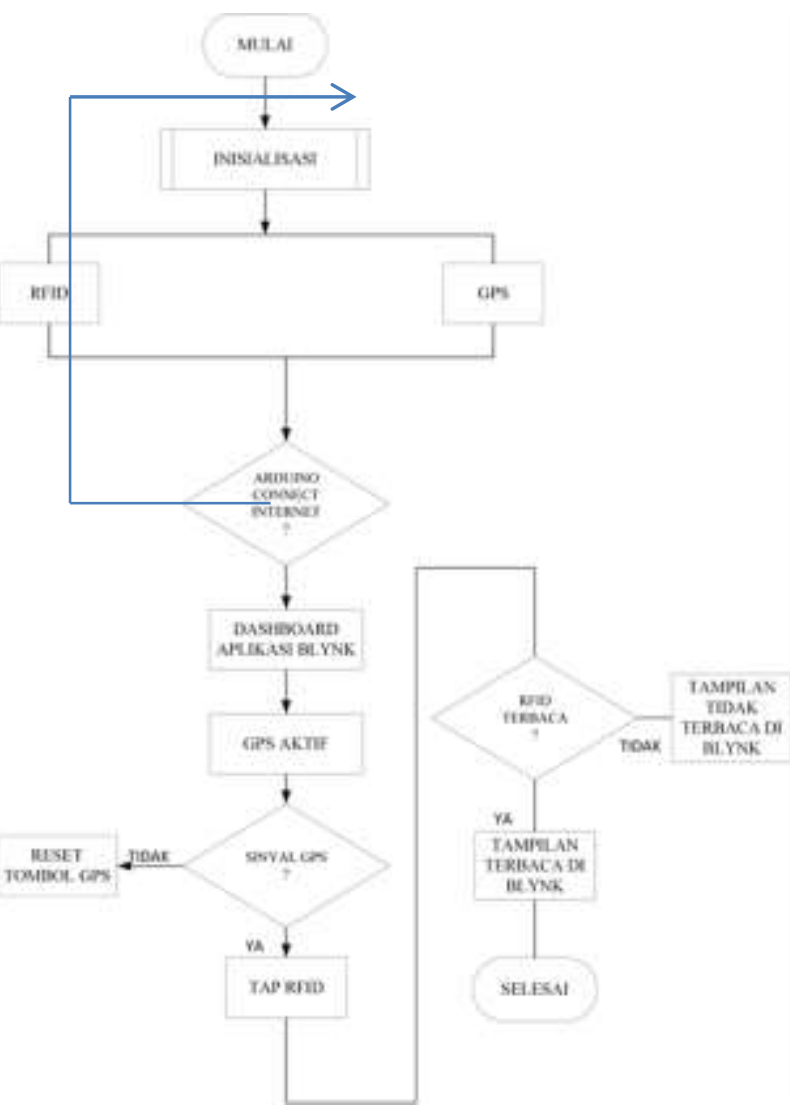

Gambar 3 Flowchart system.

Pada skematik diagram ini menunjukkan perancangan System Human Tracking menggunakan GPS dan RFID berbasis arduino.

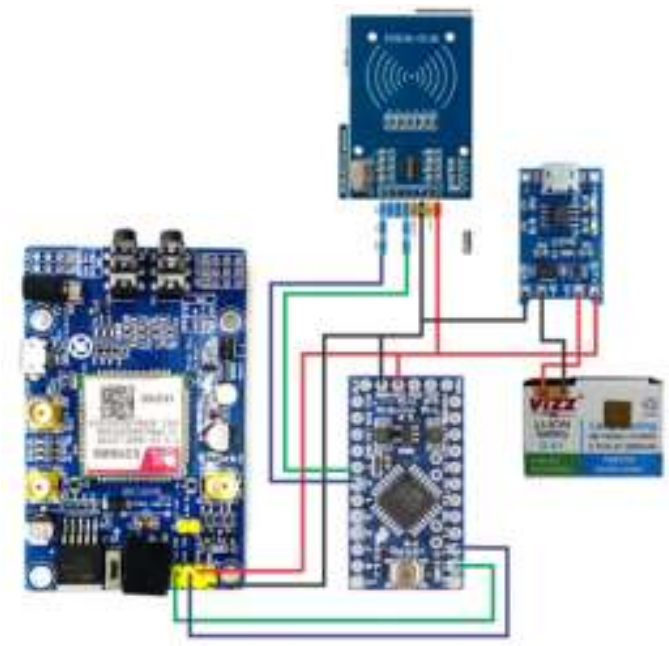

Gambar 4 Skematik diagram. 
RESISTOR (Elektronika Kendali Telekomunikasi Tenaga Listrik Komputer) Vol. 3 No. 1 e-ISSN : 2621-9700, p-ISSN : 2654-2684

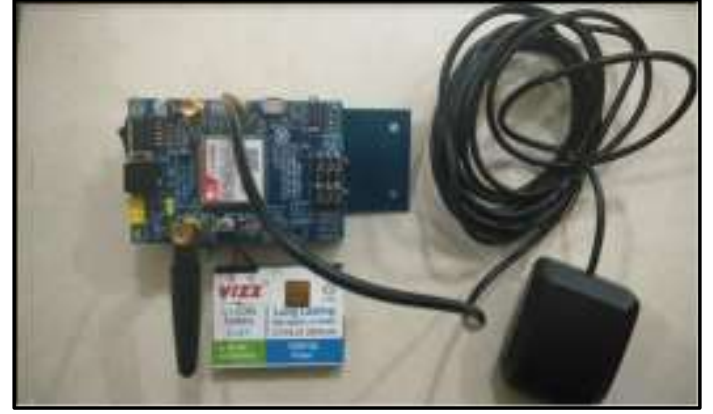

Gambar 5 Sistem human tracking tampak depan.

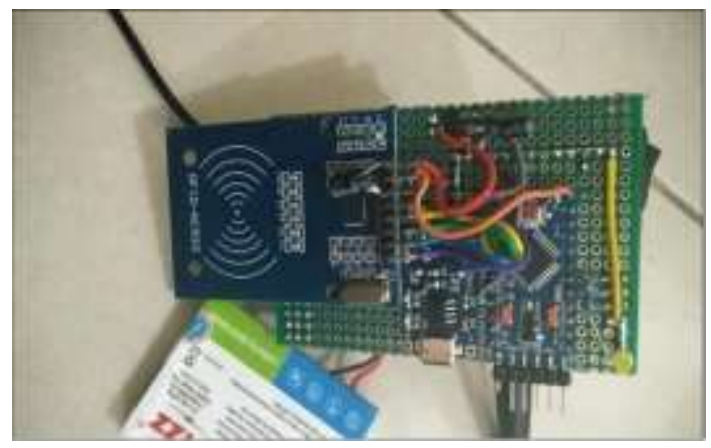

Gambar 6 Sistem human tracking tampak belakang.

Sistem Implementasi Human Tracking ini menggunakan modul SIM808 yang mana modul ini adalah 2 modul dalam satu modul yaitu GSM dan GPS yang dikontrol oleh Arduino Pro mini. Ketika Tag RFID didekatkan pada RFID Reader maka apabila terdaftar akan muncul pada dashboard aplikasi Blynk-IoT dan ketika di tap akan terlihat tanggal dan jam nya sesuai dengan maps. Untuk GPS sendiri pun akan menampilkan posisi real time si pengguna, dengan begitu dapat terpantau dengan mudah.

Langkah - langkah dalam instal aplikasi Blynk IoT pada Android :

1. Download dan Install Aplikasi android melalui "PlayStore".

2. Buka aplikasi, dan sign up new account.

3. Buat new project, kemudian pilihlah module yang akan digunakan maupun aksesoris module yang berfungsi sebagai sarana terhubung ke Internet. Dalam hal ini kita pilih module "Arduino Pro Mini”, "SIM808", dan RFID.

4. Kemudian drag and drop rancangan proyek "FinalProject".

5. Klik Blynk untuk mengirimkan Token Auth melalui email.

6. Cek inbox email dari Blynk IoT yang mana Auth Token ini akan digunakan untuk program yang didownloadkan ke module.

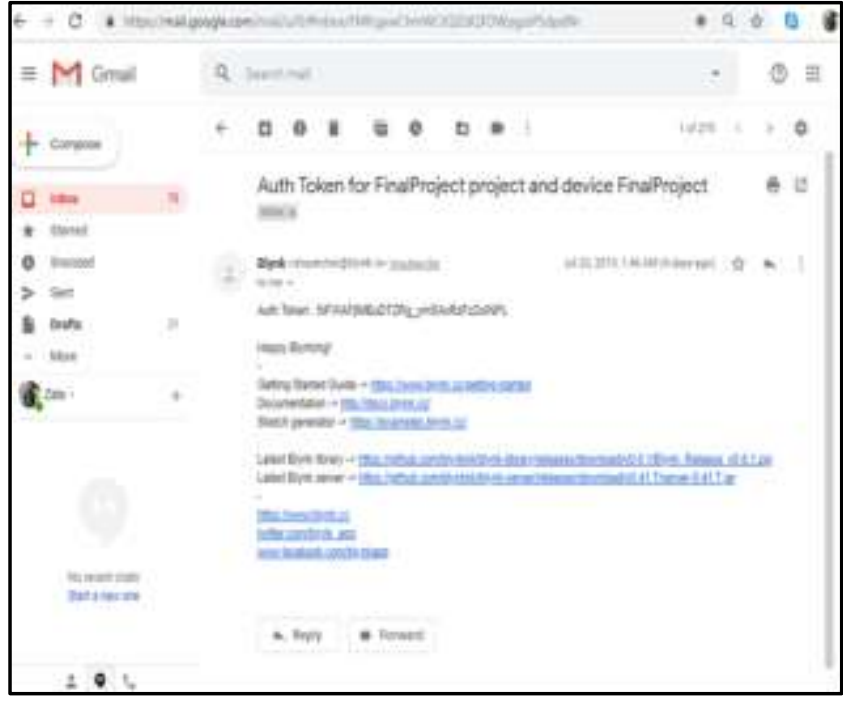

Gambar 7 Auth Token email from Blynk IoT.

\section{PENGUJIAN DAN HASIL}

Setelah tahap perancangan sistem human tracking menggunakan RFID, GPS dan arduino tersebut maka tahap selanjutnya yang dilakukan adalah tahap pengujian. Dari tahap ini, kita dapat mengetahui karakteristik setiap blok rangkaian dan fungsi alat secara keseluruhan sehingga dapat dibandingkan antara perancangan dan alat yang telah dibuat.

Pengujian Perangkat lunak dilakukan dengan membuka halaman aplikasi Android Blynk yang telah dibuat dan menghubungkan perangkat keras dengan Baterai Lithium Ion. Pada Pengujian ini, user hanya bisa memonitoring RFID yang sudah terintegrasi dengan GPS.

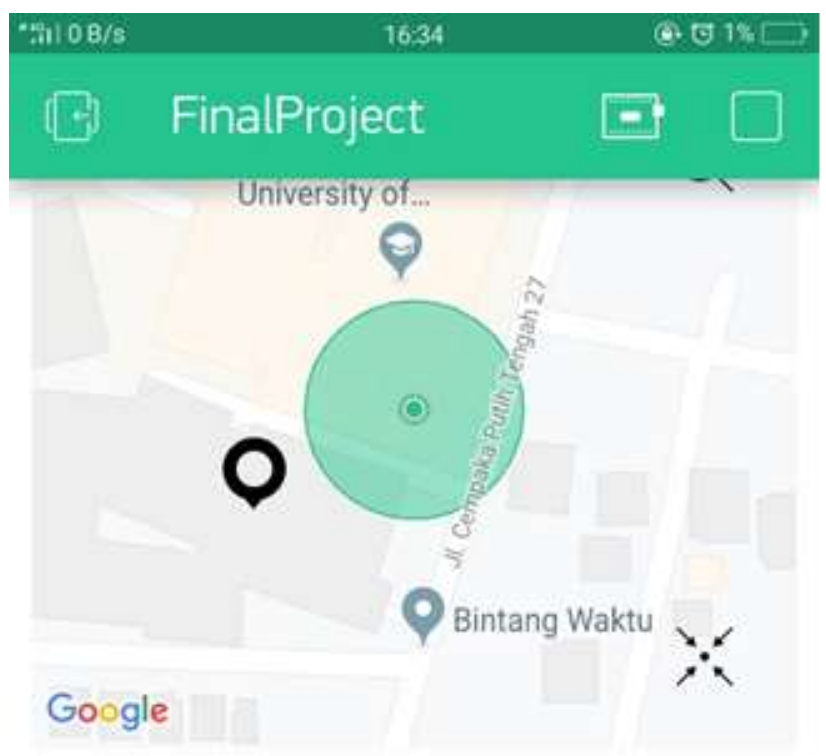

Gambar 8 Tampilan Aplikasi Blynk Human Tracking Menggunakan RFID dan GPS. 
RESISTOR (Elektronika Kendali Telekomunikasi Tenaga Listrik Komputer) Vol. 3 No. 1 e-ISSN : 2621-9700, p-ISSN : 2654-2684

Pengujian Tag dan Reader RFID yang dilakukan yaitu untuk mengetahui pada jarak berapa keberhasilan pembacaan transponder oleh RFID reader. Dan tingkat keberhasilan diukur dari jauh dekatnya tag yang di dekatkan ke RFID reader, sehingga terlihat perbedaan pada jarak berapa tag RFID terbaca dan tidak terbaca, dan terhalang benda non logam atau tidak dalam pengujiannya. RFID tag akan diuji dari jarak $0 \mathrm{~cm}$ sampai dengan jarak kritis antara sensor RFID terhadap RFID tag supaya bisa terdeteksi dengan GPS yang tertera di Aplikasi Android.

Pengujian ini dilakukan dengan cara mengukur jarak maksimal dari tag ke RFID Reader. Pengukuran ini dilakukan pada jarak $0-6 \mathrm{~cm}$ dan dilakukan secara berulang.

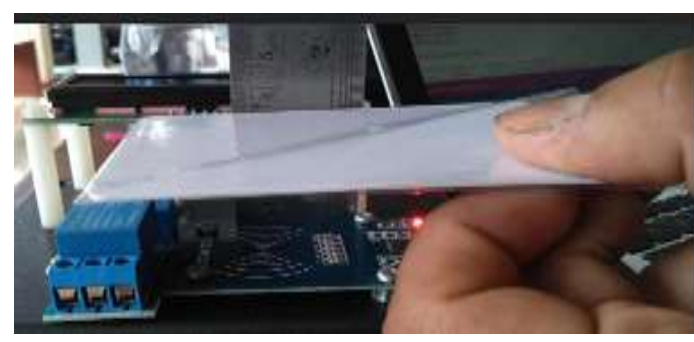

Gambar 9 Pengukuran jarak RFID.

Tabel 1 Hasil pengukuran jarak RFID.

\begin{tabular}{|c|c|c|c|}
\hline \multirow{2}{*}{ No. } & $\begin{array}{c}\text { Jarak } \\
\text { Pemba- } \\
\text { caan } \\
(\mathrm{cm})\end{array}$ & $\begin{array}{c}\text { Kondisi Pembacaan } \\
\text { Terhalang }\end{array}$ & $\begin{array}{c}\text { Terhalang } \\
\text { Benda Non } \\
\text { Logam }\end{array}$ \\
\hline 1 & 0 & Terbaca & Terbaca \\
\hline 2 & 0.5 & Terbaca & Terbaca \\
\hline 3 & 1 & Terbaca & Terbaca \\
\hline 4 & 1.5 & Terbaca & Terbaca \\
\hline 5 & 2 & Terbaca & Terbaca \\
\hline 6 & 2.5 & Terbaca & Terbaca \\
\hline 7 & 3 & Terbaca & Terbaca \\
\hline 8 & 3.5 & Terbaca & Terbaca \\
\hline 9 & 4 & Terbaca & Terbaca \\
\hline 10 & 4.5 & Terbaca & Terbaca \\
\hline 11 & 5 & Tidak Terbaca & $\begin{array}{c}\text { Tidak } \\
\text { Terbaca }\end{array}$ \\
\hline 12 & 5.5 & Tidak Terbaca & $\begin{array}{c}\text { Tidak } \\
\text { Terbaca }\end{array}$ \\
\hline 13 & 6 & Tidak Terbaca & $\begin{array}{c}\text { Tidak } \\
\text { Terbaca }\end{array}$ \\
\hline
\end{tabular}

Pada tabel 1 diatas bisa dilihat dalam hasil pengujiannya, jarak pembacaan pada pengujian tersebut yaitu membutuhkan jarak dari tag RFID ke reader RFID adalah $\leq 4.5 \mathrm{~cm}$ dalam kondisi pengujian tidak terhalang dan terhalang benda non logam. Sedangkan dalam pengujian $\geq 5 \mathrm{~cm}$ reader menunjukkan hasil tidak terbaca.

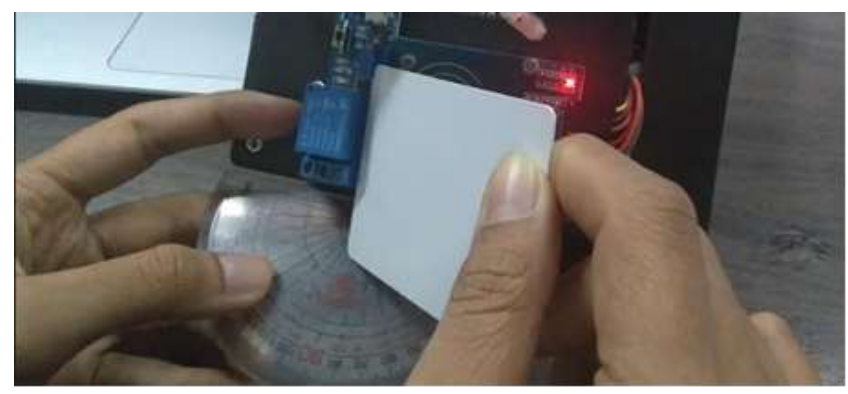

Gambar 10 Pengukuran sudut RFID.

Tabel 2 Hasil pengukuran sudut RFID.

\begin{tabular}{|c|c|c|c|}
\hline \multirow{2}{*}{ No. } & \multirow{2}{*}{$\begin{array}{c}\text { Sudut } \\
\text { Pemba- } \\
\text { caan }\left(^{\circ}\right.\end{array}$} & Tidak Terhalang & $\begin{array}{c}\text { Kondisi Pembacaan } \\
\text { Benda Non } \\
\text { Logam }\end{array}$ \\
\hline 1 & $0^{\circ}$ & Terbaca & Terbaca \\
\hline 2 & $10^{\circ}$ & Terbaca & Terbaca \\
\hline 3 & $20^{\circ}$ & Terbaca & Terbaca \\
\hline 4 & $30^{\circ}$ & Terbaca & Terbaca \\
\hline 5 & $40^{\circ}$ & Terbaca & Terbaca \\
\hline 6 & $50^{\circ}$ & Terbaca & Terbaca \\
\hline 7 & $60^{\circ}$ & Terbaca & Terbaca \\
\hline 8 & $70^{\circ}$ & Terbaca & Terbaca \\
\hline 9 & $80^{\circ}$ & Terbaca & Terbaca \\
\hline 10 & $90^{\circ}$ & Terbaca & Terbaca \\
\hline 11 & $100^{\circ}$ & Tidak Terbaca & $\begin{array}{c}\text { Tidak } \\
\text { Terbaca }\end{array}$ \\
\hline 12 & $110^{\circ}$ & Tidak Terbaca & $\begin{array}{c}\text { Tidak } \\
\text { Terbaca }\end{array}$ \\
\hline 13 & $120^{\circ}$ & Tidak Terbaca & $\begin{array}{c}\text { Tidak } \\
\text { Terbaca }\end{array}$ \\
\hline 14 & $130^{\circ}$ & Tidak Terbaca & $\begin{array}{c}\text { Tidak } \\
\text { Terbaca }\end{array}$ \\
\hline 15 & $140^{\circ}$ & Tidak Terbaca & $\begin{array}{c}\text { Tidak } \\
\text { Terbaca }\end{array}$ \\
\hline 16 & $150^{\circ}$ & Tidak Terbaca & $\begin{array}{c}\text { Tidak } \\
\text { Terbaca }\end{array}$ \\
\hline 17 & $160^{\circ}$ & Tidak Terbaca & $\begin{array}{c}\text { Tidak } \\
\text { Terbaca }\end{array}$ \\
\hline 18 & $170^{\circ}$ & Tidak Terbaca & Tidak \\
\hline
\end{tabular}


RESISTOR (Elektronika Kendali Telekomunikasi Tenaga Listrik Komputer) Vol. 3 No. 1 e-ISSN : 2621-9700, p-ISSN : 2654-2684

\begin{tabular}{|c|c|c|c|} 
& & & Terbaca \\
\hline 19 & $180^{\circ}$ & Tidak Terbaca & $\begin{array}{c}\text { Tidak } \\
\text { Terbaca }\end{array}$ \\
\hline
\end{tabular}

Pada tabel 2 bisa dilihat dalam hasil pengujiannya, jarak pembacaan pada pengujian tersebut yaitu membutuhkan jarak dari tag RFID ke reader RFID adalah $\leq 90^{\circ}$ dalam kondisi pengujian tidak terhalang dan terhalang benda non logam. Sedangkan dalam pengujian sudutnya $\geq 100^{\circ}$ reader menunjukkan hasil tidak terbaca.

Pada pengujian yang dilakukan akan menampilkan ID karyawan yang terdaftar dan tidak terdaftar dan mengetahui lokasi karyawan tersebut melalui aplikasi android Blynk IoT.

Tabel 3 Hasil pengukuran keseluruhan RFID.

\begin{tabular}{|c|c|c|c|c|}
\hline No & $\begin{array}{c}\text { Kondisi } \\
\text { Pembacaan } \\
\text { RFID }\end{array}$ & $\begin{array}{c}\text { Kondisi } \\
\text { GPS }\end{array}$ & $\begin{array}{c}\text { Notifikasi Aplikasi } \\
\text { Blynk }\end{array}$ & $\begin{array}{c}\text { Waktu } \\
\text { Pembaca } \\
\text { an }\end{array}$ \\
\hline 1 & Terbaca & On & $\begin{array}{c}\text { User Karyawan Terdaftar } \\
\text { (ZATA) }\end{array}$ & 3 Detik \\
\hline 2 & Terbaca & On & $\begin{array}{c}\text { User Karyawan Terdaftar } \\
\text { (rasyid) }\end{array}$ & 3 Detik \\
\hline 3 & Tidak Terbaca & On & $\begin{array}{c}\text { User Karyawan Tidak } \\
\text { Terdaftar (UNKNOWN) }\end{array}$ & 3 Detik \\
\hline
\end{tabular}
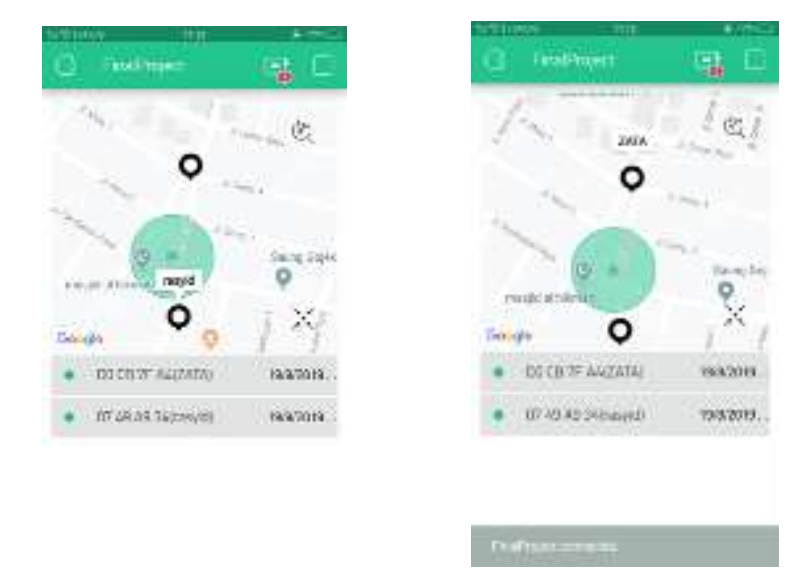

Gambar 11 Pengujian RFID yang terdaftar pada aplikasi Blynk IoT.

Pada gambar diatas terlihat bahwa dapat dipantau beberapa RFID dan posisinya secara real time.

\section{KESIMPULAN}

Berdasarkan dari perencanaan alat dan hasil pengujian rangkaian maka dapat disimpulkan beberapa hal sebagai berikut :

1. Pada pengujian RFID, jarak maksimal yang dapat dideteksi antara RFID reader dan tag RFID adalah pada jarak $4.5 \mathrm{~cm}$.
2. Pada pengujian RFID untuk sudutnya yang dapat dideteksi antara RFID reader dan tag RFID adalah pada sudut $0^{\circ}-90^{\circ}$ dan $120^{\circ}$ $180^{\circ}$.

3. Pada pengujian pembacaan RFID pada aplikasi android Blynk IoT, untuk RFID yang terpantau akan menampilkan nama ID yang telah didaftarkan dan posisinya secara real time. Dalam 1 dashboard project dapat menampilkan beberapa RFID yang telah didaftarkan untuk dipantau.

\section{DAFTAR PUSTAKA}

[1] A. F. Prasetyo, "Rancang Bangun Smart Fish Berbasis Iot Menggunakan Aplikasi Blynk," Politeknik Negeri Balikpapan, Balikpapan, 2018.

[2] N. Arifianto and M. A. Fahrizal, "Pengaman Kendaraan Bermotor dengan Remote Android Berbasis Gsm, Gps, dan Bluetooth," Institut Teknologi Sepuluh Nopember, 2017.

[3] Y. Yuliza and H. Pangaribuan, "Rancang bangun kompor listrik digital IOT," Jurnal Teknologi Elektro, vol. 7, no. 3, 2016.

[4] A. Kadir, "Panduan Praktis Mempelajari aplikasi mikrokontroler dan pemrogramannya menggunakan Arduino," Yogyakarta: Andi, 2013.

[5] S. Bahri and P. S. Yuza, "Analisa Kerusakan (Deformasi) Engine Mounting Kendaraan Toyota Agya Berdasarkan Tingkat Vibrasi Berbasis Mem Accelerometer," RESISTOR (elektRonika kEndali telekomunikaSI tenaga liSTrik kOmputeR), vol. 2, no. 2, pp. 131-136, 2019.

[6] E. Dermawan, P. G. Chamdareno, and A. R. Priyono, "Studi Analisa Start-Up Gas Turbin Memanfaatkan Generator Utama sebagai Motor Penggerak Mula dengan Menggunakan Static Frequency Converter (Sfc) pada Unit Blok 1-2 PT. PJB Unit Pembangkitan Muara Tawar," RESISTOR (elektRonika kEndali telekomunikaSI tenaga liSTrik kOmputeR), vol. 2, no. 2, pp. 83-88, 2019.

[7] B. Budiyanto and F. Fadliondi, "The Improvement of Solar Cell Output Power Using Cooling and Reflection from Mirror," International Journal of Power Electronics and Drive Systems, vol. 8, no. 3, p. 1320, 2017.

[8] P. G. Chamdareno, E. Dermawan, and H. Octafriandi, "Desain dan Analisa Permanen 
RESISTOR (Elektronika Kendali Telekomunikasi Tenaga Listrik Komputer) Vol. 3 No. 1 e-ISSN : 2621-9700, p-ISSN : 2654-2684

Magnet Motor Sinkron untuk Aplikasi pada Lift," RESISTOR (elektRonika kEndali telekomunikaSI tenaga liSTrik kOmputeR), vol. 2, no. 2, pp. 113-120, 2019.

[9] F. Fadliondi, H. Isyanto, and P. G. Chamdareno, "The comparison of organic field effect transistor (OFET) structures," in 2017 2nd International Conference on Frontiers of Sensors Technologies (ICFST), 2017, pp. 6-9.

[10] H. Muchtar and F. Said, "Sistem Identifikasi Plat Nomor Kendaraan Menggunakan Metode Robert Filter dan Framing Image Berbasis Pengolahan Citra Digital," RESISTOR (elektRonika kEndali telekomunikaSI tenaga liSTrik kOmputeR), vol. 2, no. 2, pp. 105-112, 2019.

[11] R. Samsinar, D. Almanda, and E. Priatna, "Sistem Pengingat Ganti Oli Berdasarkan Running Hours Mesin, Lama Waktu Pemakaian dan Kekentalan Oli pada Mesin Wire Drawing Berbasis Raspberry Pi 1," RESISTOR (elektRonika kEndali telekomunikaSI tenaga liSTrik kOmputeR), vol. 2, no. 2, pp. 121-130, 2019.

[12] D. Almanda and B. P. Piliang, "Perbandingan Sistem Pendingin pada Konsentrasi Water Coolant, Air Mineral, dan Air Laut Menggunakan Panel Surya Fleksibel Monocrystaline 20 Wp," RESISTOR (elektRonika kEndali telekomunikaSI tenaga liSTrik kOmputeR), vol. 2, no. 2, pp. 73-82, 2019.

[13] F. Fadliondi, B. Budiyanto, H. Isyanto, and P. G. Chamdareno, "Effects of Several Parameters on Thermoelectricity," vol. 62, no. 02, p. 6, 2020.

[14] F. Fadliondi, M. Kunta Biddinika, and S. I. Omi, "The Humidity Dependence of Pentacene Organic Metal-OxideSemiconductor Field-Effect Transistor.," Telkomnika, vol. 15, no. 2, 2017.

[15] F. Fadliondi, H. Isyanto, and B. Budiyanto, "Bypass Diodes for Improving Solar Panel Performance," International Journal of Electrical and Computer Engineering, vol. 8, no. 5, p. 2703, 2018.

[16] H. Isyanto and I. Jaenudin, "MONITORING DUA PARAMETER DATA MEDIK PASIEN (SUHU TUBUH DAN DETAK JANTUNG)
BERBASIS ARUINO NIRKABEL," eLEKTUM, vol. 15, no. 1, pp. 19-24, 2018.

[17] H. Isyanto, A. Solikhin, and W. Ibrahim, "Perancangan dan Implementasi Security System pada Sepeda Motor Menggunakan RFID Sensor Berbasis Raspberry Pi," RESISTOR (elektRonika kEndali telekomunikaSI tenaga liSTrik kOmputeR), vol. 2, no. 1, pp. 29-38, 2019.

[18] S. Alfeno and R. E. C. Devi, "Implementasi Global Positioning System (GPS) dan Location Based Service (LSB) pada Sistem Informasi Kereta Api untuk Wilayah Jabodetabe," Jurnal Sisfotek Global, vol. 7, no. 2, 2017. 
RESISTOR (Elektronika Kendali Telekomunikasi Tenaga Listrik Komputer) Vol. 3 No. 1 e-ISSN : 2621-9700, p-ISSN : 2654-2684 